\title{
The combinatory effects of PPAR- $\gamma$ agonist and survivin inhibition on the cancer stem-like phenotype and cell proliferation in bladder cancer cells
}

\author{
YANG WANG ${ }^{1}$, HAILIN TAN ${ }^{1,3}$, DONGXU XU ${ }^{2}$, AIHUI MA ${ }^{2}$, LI ZHANG $^{2}$, JIABIN SUN $^{2}$, \\ ZHAOJUAN YANG ${ }^{2}$, YONGZHONG LIU $^{2}$ and GUOWEI SHI ${ }^{1,4}$
}

\begin{abstract}
${ }^{1}$ Department of Urology, Shanghai No. 5 People's Hospital, Fudan University, Shanghai; ${ }^{2}$ State Key Laboratory of Oncogenes and Related Genes, Shanghai Jiao Tong University School of Medicine, Renji Hospital, Shanghai Cancer Institute, Shanghai;

${ }^{3}$ Department of Urology, The Affiliated Hospital of Medical College of Qingdao University, Qingdao;

${ }^{4}$ Fudan Institute of Urology, Huashan Hospital, Fudan University, Shanghai, P.R. China
\end{abstract}

Received November 29, 2013; Accepted April 17, 2014

DOI: $10.3892 / \mathrm{ijmm} .2014 .1774$

\begin{abstract}
Strategies for peroxisome proliferator-activated receptor (PPAR) activation or survivin inhibition have potential for cancer therapy. However, whether the combination of these two approaches can be developed as a rational regimen with enhanced efficiency in the inhibition of tumor cells remains to be determined. In this study, the combinatory effect of PPAR- $\gamma$ agonist and survivin inhibition on bladder cancer cells was investigated. T24 and 5637 cells were treated with $15 \mathrm{~d}-\mathrm{PGJ}_{2}$ to determine whether $15 \mathrm{~d}-\mathrm{PGJ}_{2}$ had an inhibitory effect. Cell viability and proliferation were analyzed and efficiency of survivin siRNAs was assessed using western blot analysis. The results showed that, in the human bladder cancer cell lines T24 and 5637, the natural PPAR- $\gamma$ ligand $15 \mathrm{~d}_{-} \mathrm{PGJ}_{2}$ significantly decreased cell proliferation and loci formation. The increase in the proportion of apoptotic cells was observed in the cells $48 \mathrm{~h}$ after $15 \mathrm{~d}-\mathrm{PGJ}_{2}$ treatment. Furthermore, $15 \mathrm{~d}-\mathrm{PGJ}_{2}$ substantially inhibited the levels of stemness-related genes in these cells. The ability of sphere formation was markedly suppressed in the cells treated with $15 \mathrm{~d}_{-} \mathrm{PGJ}_{2}$. More importantly, the downregulation of survivin with siRNAs significantly enhanced the $15 \mathrm{~d}-\mathrm{PGJ}_{2}$-mediated induction of cell apoptosis and inhibition of sphere formation. Accordingly, we also found that survivin inhibition significantly enhanced $15 \mathrm{~d}-\mathrm{PGJ}_{2}$-induced production of reactive oxygen species (ROS) in bladder cancer cells. Taken together, these findings suggest that the combination of $15 \mathrm{~d}^{-} \mathrm{PGJ}_{2}$ and survivin inhibition play a potentially role in the therapeutical manipulation of bladder cancer.
\end{abstract}

Correspondence to: Dr Guowei Shi, Department of Urology, Shanghai No. 5 People's Hospital, Fudan University, 128 Ruili Road, Shanghai 200240, P.R. China

E-mail: dr.sgw@189.cn

Key words: peroxisome proliferator-activated receptor- $\gamma$ agonist, survivin, cancer stem-like phenotype

\section{Introduction}

The incidence of bladder cancer, a common urologic cancer, continues to increase annually, ranking as the ninth most common malignancy wordwide (1). Although treatment with systemic chemotherapy is recommended, the prognosis for patients with metastatic bladder cancer is poor. Therefore, improvement of existing therapies and development of alternative therapeutic approaches is critical. Recent advances in the study on tumor-initiating cells, a small subpopulation of tumor cells that contribute to tumor initiation, metastasis and drug-resistance (2), suggest that targeting these cells may lead to novel therapies that can be utilized in the reduction of risk of tumor recurrence.

The peroxisome proliferator-activated receptor- $\gamma($ PPAR- $\gamma)$ is a member of the nuclear receptor superfamily that is activated by its ligands. The activation of PPAR- $\gamma$ may lead to cell growth arrest, apoptosis, decrease of cell adhesion and migration, and particularly, result in the differentiation of cancer cells (3). The property of their antigrowth and prodifferentiation renders natural and synthetic ligands of PPAR- $\gamma$ as attractive substances in cancer prevention and treatment (3-6). However, given that PPAR- $\gamma$ ligands often trigger crosstalk with other signalling pathways (6-8), use of PPAR- $\gamma$ agonists alone on much more common advanced epithelial malignancies has minimal clinical effect (9). Therefore, the combination of PPAR- $\gamma$ agonists with other drugs, such as EGFR inhibitor (10) or AKT inhibitor (11) has been examined for cancer treatment.

One of the hallmarks of tumor cells is the ability to evade apoptosis (12). Overexpression of antiapoptotic genes is one of mechanisms to escape cancer cell apoptosis. As an important member of the inhibitor of apoptosis gene family, survivin can block the activation of effector caspases in intrinsic and extrinsic pathways of apoptosis. Survivin is absent in normal urothelium, whereas it is present in $64-100 \%$ of bladder cancers (13). Moreover, the expression of survivin is associated with high stage and grade as well as with an increase risk of recurrence for patients with bladder cancer (14-17). 
Thus, survivin has been suggested as a suitable target for the development of specific treatment of bladder cancer (15). In the present study, we report that the combination of PPAR- $\gamma$ activation and survivin inhibition generates a more robust suppression in the cell survival and stem cell properties of bladder cancer cells, providing a basis for future studies testing the strategy for experimental manipulation of bladder cancer.

\section{Materials and methods}

Cell culture. The human bladder cancer cell lines, T24 and 5637, obtained from the American Type Culture Collection (Manassas, VA, USA), were cultured in a maintenance medium containing DMEM with high glucose supplemented with $10 \%$ fetal bovine serum and penicillin/streptomycin $[1 \%(\mathrm{v} / \mathrm{v})]$ (all from Gibco, Grand Island, NY, USA). The cells were then treated with $15 \mathrm{~d}_{-} \mathrm{PGJ}_{2}$ (Sigma-Aldrich, St. Louis, MO, USA) for the indicated times (6 days). Cell cultures were maintained at $37^{\circ} \mathrm{C}$ in a humidified atmosphere with $5 \% \mathrm{CO}_{2}$.

siRNA of survivin. Survivin RNAi oligos and negative control high GC oligo were purchased from Sigma-Aldrich. The siRNA sequences are listed in Table I. One day prior to the transfection, T24 and 5637 cells were seeded in 6-well plates without antibiotics. Using Lipofectamine 2000 (Invitrogen, Carlsbad, CA, USA), the siRNAs (60 nM) were transfected into the cells according to the manufacturer's instructions.

Cell viability assay. To evaluate the effect of $15 \mathrm{~d}-\mathrm{PGJ}_{2}$ on T24 and 5637 cell growth, cell viability was determined by the 3-(4,5-dimethyl-2-thiazolyl)-2,5-diphenyl-2H-tetrazolium bromide (MTT) (Sigma-Aldrich) assay. In brief, a total of 1,000 5637 or 5,000 T24 cells/well were seeded in 96-well plates (BD Biosciences, San Jose, CA, USA) in a volume of $200 \mu \mathrm{l}$. Subsequent to incubation with 0.5 or $2 \mu \mathrm{g} / \mathrm{ml} 15 \mathrm{~d}-\mathrm{PGJ}_{2}$ for the indicated times, $20 \mu \mathrm{l}$ MTT solution $[5 \mathrm{mg} / \mathrm{ml}$ in phosphate-buffered saline (PBS)] was added to each well and incubated for an additional $4 \mathrm{~h}$ at $37^{\circ} \mathrm{C}$. MTT solution was aspirated off, $150 \mu \mathrm{l}$ dimethyl sulfoxide (DMSO) was added to each well, and the absorbance was measured at $540 \mathrm{~nm}$. Data were recorded on a daily basis and the growth curve was drawn.

Cell cycle analysis. Cells were collected and centrifuged at $300 \mathrm{x} \mathrm{g}$ at $4^{\circ} \mathrm{C}$ for $5 \mathrm{~min}$ and resuspended by PBS in tubes. The abovementioned steps were then repeated. The cells were fixed in ice-cold $70 \%$ ethanol overnight. After washing with PBS twice, the cells were labelled with propidium iodide (PI) $(50 \mu \mathrm{g} / \mathrm{ml}$; Sigma-Aldrich) and treated with RNase A (100 $\mu \mathrm{g} / \mathrm{ml}$; Amresco, Solon, OH, USA) for $30 \mathrm{~min}$ in the dark. The cells were then analyzed using a FACSCalibur flow cytometer (BD Biosciences).

Apoptosis assay. T24 and 5637 cells were collected, centrifuged at $300 \mathrm{x} \mathrm{g}$ at $4^{\circ} \mathrm{C}$ for $5 \mathrm{~min}$, and washed twice with PBS containing $0.5 \% \mathrm{BSA}$. The cells were dissociated in $1 \mathrm{X}$ binding buffer and the cell concentration was adjusted to $1 \times 10^{6} / \mathrm{ml}$. Cell suspension $(100 \mu \mathrm{l})$ was added with Annexin V-FITC (BD Biosciences) and 7-AAD (Sigma-Aldrich) according to the manufacturer's instructions, and incubated for $20 \mathrm{~min}$ in
Table I. List of siRNA sequences.

\begin{tabular}{llc} 
Name & \multicolumn{2}{c}{ siRNA sequence } \\
\hline siSurvivin1 & F & GUCUGGACCUCAUGUUGUUdTdT \\
& R & AACAACAUGAGGUCCAGACdTdT \\
siSurvivin2 & F & CCUCUACUGUUUAACAACAdTdT \\
& R & UGUUGUUAAACAGUAGAGGdTdT \\
siSurvivin3 & F & GGUUUAUUCCCUGGUGCCAdTdT \\
& R & UGGCACCAGGGAAUAAACCdTdT
\end{tabular}

F, forward; R, reverse.

the dark. Following the addition of $200 \mu \mathrm{l} 1 \mathrm{X}$ binding buffer in the tube, FACS was performed.

Western blot analysis. Cells were lysed in a RIPA lysis buffer (Beyotime, Nantong, China) with Protease Inhibitor Cocktail and PhosSTOP (Roche, Monza, IT, USA). Proteins were detected using indicated antibodies: anti-PPAR- $\gamma$, antisurvivin (all from Cell Signaling Technology, Beverly, MA, USA); anti-GAPDH, anti- $\alpha$-tubulin (both from Santa Cruz Biotechnology, Inc., Santa Cruz, CA, USA). The ChemiDoc ${ }^{\mathrm{TM}}$ XRS system (Bio-Rad Laboratories, Hercules, CA, USA) was used for obtaining images.

Sphere formation assay. To assay sphere formation efficiency, single cells were plated in Ultra Low Attachment plates (Costar, Corning, NY, USA) and cultured in 1:1 DMEM:F12 (Gibco) supplemented with B27 (1:50; Invitrogen), $20 \mathrm{ng} / \mathrm{ml}$ epidermal growth factor and $20 \mathrm{ng} / \mathrm{ml}$ basic fibroblast growth factor (R\&D Systems, Minneapolis, MN, USA). The cells were incubated in a $\mathrm{CO}_{2}$ incubator for 1-2 weeks, and spheres were counted under a stereomicroscope (Olympus, Tokyo, Japan).

Measurement of reactive oxygen species (ROS) accumulation. ROS was monitored by FACS using dihydroethidium (DHE) (Invitrogen). Cells were incubated with $5 \mu \mathrm{M} \mathrm{DHE}$ at $37^{\circ} \mathrm{C}$ for $30 \mathrm{~min}$, and fluorescence was measured by a FACSCalibur flow cytometer.

Statistical analysis. Data are presented as the means \pm SEM. Statistical analyses were conducted using SPSS 13.0 for Windows. Data between two groups were assessed using the Student's t-test. $\mathrm{P}<0.05$ was considered to indicate statistical significance.

\section{Results}

15d-PGJ $\mathrm{J}_{2}$ effectively inhibits cell proliferation and stem cell-like properties of bladder cancer cells. Since PPAR- $\gamma$ agonists are known to inhibit cell growth in various types of cancer cells (18-20), we first detected the effect of $15 d-P G J_{2}$, a natural PPAR- $\gamma$ ligand, on the cell viability of bladder cancer cells. T24 and 5637 cells were treated with $15 \mathrm{~d}_{-} \mathrm{PGJ}_{2}$ at various concentrations for the indicated times (6 days). 15d-PGJ efficiently suppressed T24 and 5637 cell growth (Fig. 1A). Similarly, we observed the inhibitory effect of $15 \mathrm{~d}^{-P G J} \mathrm{~J}_{2}$ on 
A

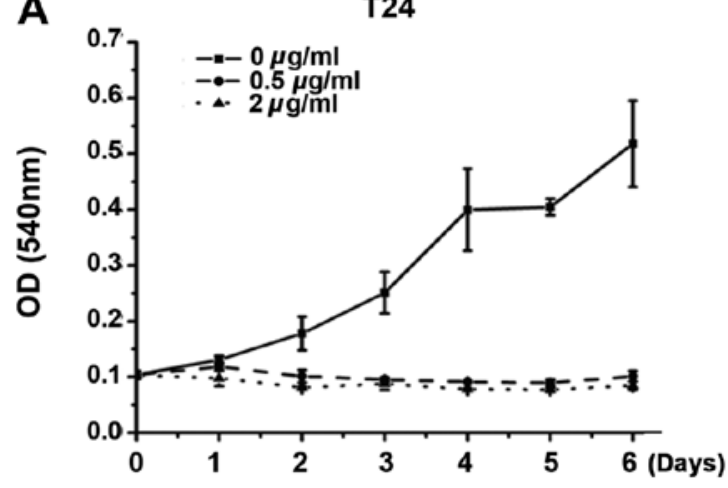

B

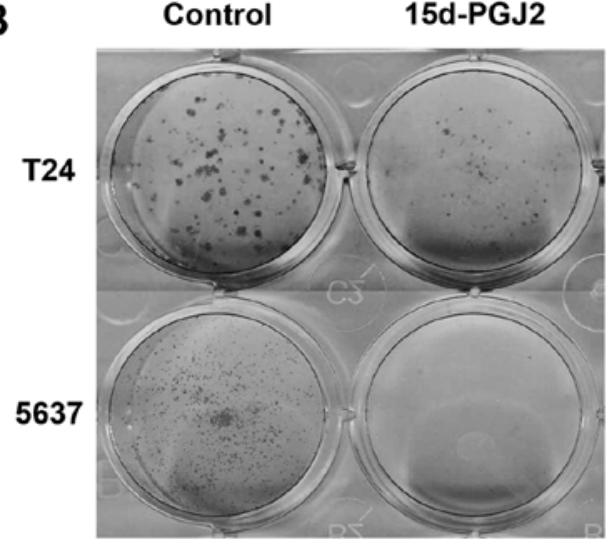

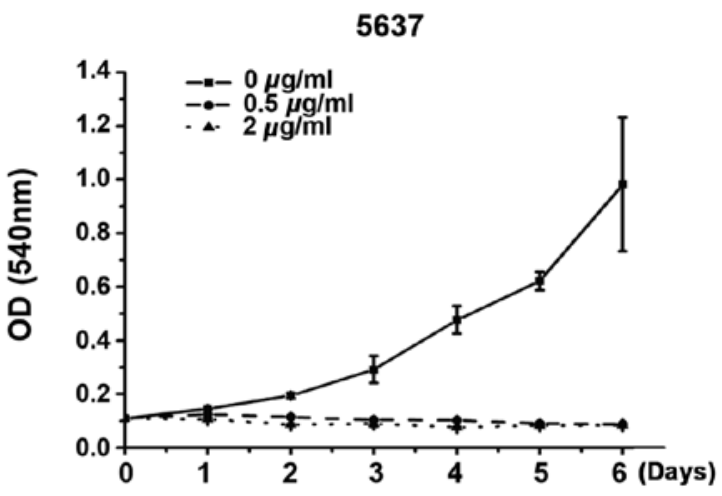

C

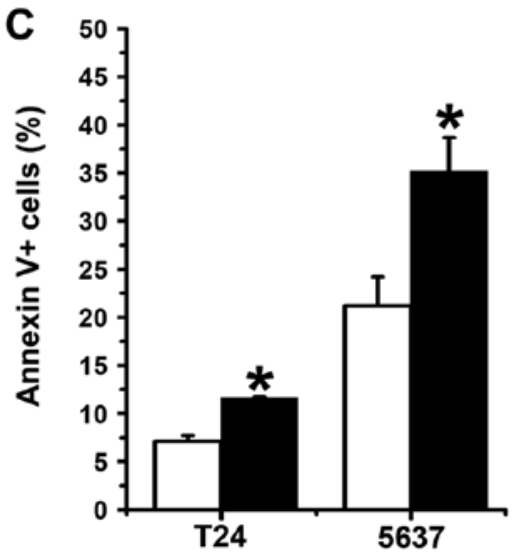

Figure 1. Suppressive effects of $15 \mathrm{~d}-\mathrm{PGJ}_{2}$ on cell viability and proliferation of bladder cancer cells. (A) Effect of $15 \mathrm{~d}-\mathrm{PGJ} \mathrm{J}_{2}$ on viability of T24 and 5637 cells. T24 and 5637 cells were treated with $15-\mathrm{PGJ}_{2}(0.5$ or $2 \mu \mathrm{g} / \mathrm{ml})$ for the indicated times. Cell proliferation was analyzed by MTT assay. Data are the means \pm standard error of the mean (SEM) $(n=3)$. (B) Representative image of dense foci formation of T24 and 5637 cells following treatment with or without $15 \mathrm{~d}-\mathrm{PGJ}_{2}(0.5 \mu \mathrm{g} / \mathrm{ml})$ for 7 days. (C) T24 and 5637 cells were treated with $0.5 \mu \mathrm{g} / \mathrm{ml} 15 \mathrm{~d}-\mathrm{PGJ}_{2}$ for $48 \mathrm{~h}$, and the percentage of apoptotic cells was detected by Annexin V-FITC/7-AAD staining. Quantitative bar graphs show the means \pm SEM $(n=3)$. ${ }^{*}<0.05$, compared with control cells.

bladder cancer cells by measurement of foci formation and cell apoptosis (Fig. 1B and C).

Since PPAR- $\gamma$ agonists have been observed to regulate differentiation of myxoid/round cell liposarcoma (21) and inhibit tumor-initiating cells in brain and liver cancers (22), we investigated the possibility that $15 \mathrm{~d}-\mathrm{PGJ}_{2}$ treatment affects the stem cell-like properties of bladder cancer cells. The expression of the stemness-related genes, Oct4 and Nanog, was significantly downregulated in T24 and 5637 cells following the treatment of 15d-PGJ ${ }_{2}$ (Fig. 2A). Of note, the decreased expression of Oct4 and Nanog genes was observed starting $\sim 1 \mathrm{~h}$ after treatment with $15 \mathrm{~d}-\mathrm{PGJ}_{2}$ in T24 cells, suggesting the key role of $15 \mathrm{~d}-\mathrm{PGJ}_{2}$ on the repression of the stem-like phenotype of bladder cancer cells. We also performed a speroid formation assay. The results showed that $15 \mathrm{~d}-\mathrm{PGJ}_{2}$ treatment at low concentrations had no significant effect on the spheroid formation of T24 or 5637 cells (Fig. 2B). Only the treatment with a high dose of $15 \mathrm{~d}_{-} \mathrm{PGJ}_{2}$ (up to $5 \mu \mathrm{g} / \mathrm{ml}$ ) decreased the spheroid number that bladder cancer cells formed (Fig. 2B), suggesting that the treatment of $15 \mathrm{~d}_{-}-\mathrm{PGJ}_{2}$ alone is not sufficient to prevent bladder cancer.

Survivin inhibition accelerates the suppressive effect of $15 \mathrm{~d}_{-} \mathrm{PGJ}_{2}$ on cell proliferation and the stem cell-like properties of bladder cancer cells. The anti-apoptotic protein survivin has been demonstrated as a promising biomarker for detection and prognosis in bladder cancer. Thus, we hypothesized whether the combination of $15 \mathrm{~d}-\mathrm{PGJ}_{2}$ and survivin inhibition may more efficiently inhibit cell growth and the stem-like phenotype of bladder cancer cells as compared to the single treatment of $15 \mathrm{~d}-\mathrm{PGJ}_{2}$. We first evaluated the expression of survivin in $15 \mathrm{~d}-\mathrm{PGJ}_{2}$-treated bladder cancer cells. The results showed no significant difference in the expression of survivin between the cells treated with or without $15 \mathrm{~d}_{-} \mathrm{PGJ}_{2}$ (Fig. 3), suggesting that downregulation of survivin may increase the efficiency of $15 \mathrm{~d}-\mathrm{PGJ}_{2}$ treatment. Survivin expression was depleted with specific siRNAs in the T24 and 5637 cells and the effectiveness of survivin siRNAs was validated by western blotting (Fig. 4A). In the presence of $15 \mathrm{~d}-\mathrm{PGJ}_{2}$, we found that inhibition of survivin expression by specific siRNAs increased cell apoptosis induced by $15 \mathrm{~d}-\mathrm{PGJ}_{2}$ (Fig. 4B). Moreover, siRNAs against survivin strengthened the suppressive effect of $15 \mathrm{~d}-\mathrm{PGJ}_{2}$ on the spheroid formation of T24 cells (Fig. 5A). Notably, the downregulation of survivin by siRNA did not facilitate $15 \mathrm{~d}-\mathrm{PGJ}_{2}$-mediated inhibition of the stemness-related genes in 5637 cells, even if survivin depletion alone affected the expression of Oct4 and Nanog (Fig. 5B), suggesting that survivin inhibition by siRNAs exacerbated the inhibitory effects of $15 \mathrm{~d}-\mathrm{PGJ}_{2}$ on bladder cancer cells by directly inducing cell death.

$15 d-P G J_{2}$ enhances survivin inhibition-induced production of $R O S$ in bladder cancer cells. Since oxidative stress is one of the most important regulatory mechanisms for cell apoptosis and 
A
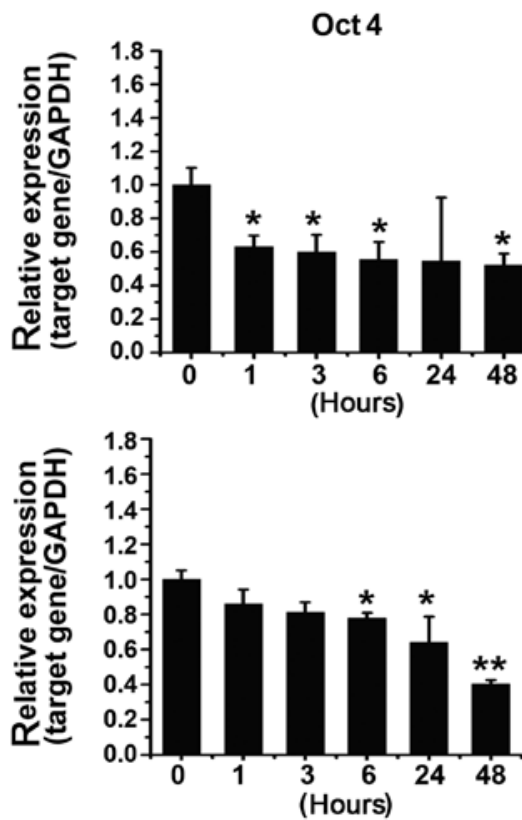

B

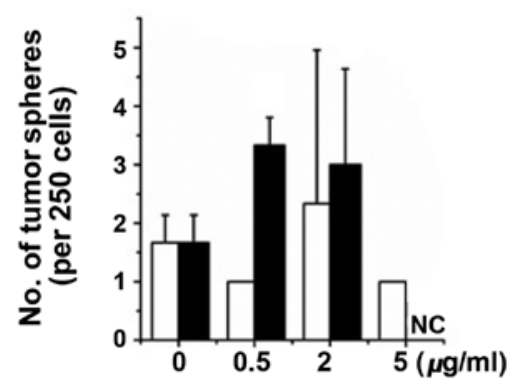

Nanog
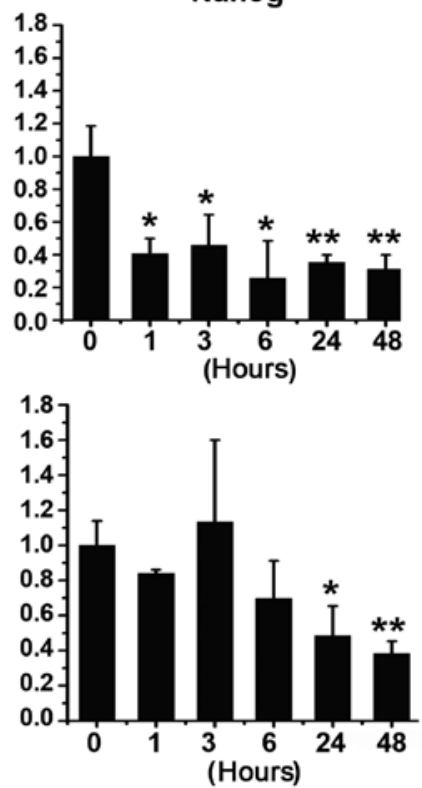

5637

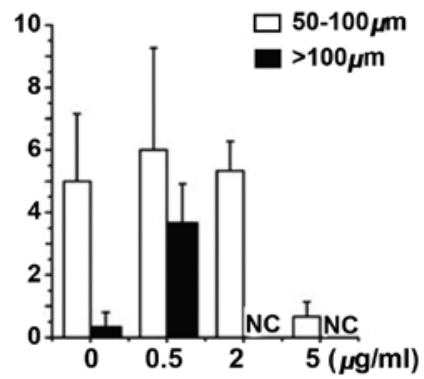

Figure 2. $15 \mathrm{~d}-\mathrm{PGJ}_{2}$ inhibits the stem cell-like properties of bladder cancer cells. (A) T24 and 5637 cells were treated with $0.5 \mu \mathrm{g} / \mathrm{ml} 15 \mathrm{~d}-\mathrm{PGJ} \mathrm{J}_{2}$ for the indicated times. The expression of stemness-related genes was detected by quantitative RT-PCR analysis. Quantitative bar graphs are shown [means \pm standard error of the mean (SEM), $\mathrm{n}=3$ ]. ${ }^{*} \mathrm{P}<0.05$ and $^{* *} \mathrm{P}<0.01$, compared with the control cells. (B) T24 and 5637 cells were cultured in spheroid-forming medium containing various concentrations of $15 \mathrm{~d}-\mathrm{PGJ}_{2}(0.5 \mu \mathrm{g} / \mathrm{ml})$ for 7 days. Data are the means $\pm \operatorname{SEM}(\mathrm{n}=3)$.

differentiation (23-25), we evaluated the generation of ROS in bladder cancer cells treated with $15 \mathrm{~d}-\mathrm{PGJ}_{2}$ or transfected with survivin-specific siRNAs. Depleting the survivin expression significantly induced the production of ROS in the T24 and 5637 cells, and $15 \mathrm{~d}-\mathrm{PGJ}_{2}$ further facilitated the generation of ROS (Fig. 5C and D). The upward trend in ROS was consistent with an increase of cell apoptosis induced by $15 \mathrm{~d}-\mathrm{PGJ}_{2}$ and/or survivin inhibition (Fig. 4B), suggesting that generation of ROS may be responsible for the inhibition of cell proliferation-mediated $15 \mathrm{~d}-\mathrm{PGJ}_{2}$ and/or survivin in bladder cancer cells.

\section{Discussion}

PPAR- $\gamma$ participates in multiple biological pathways, such as lipid metabolism, energy homeostasis, cell proliferation, death and differentiation $(26,27)$, and various pathogenic processes including inflammation, diabetes, atherosclerosis and cancer (28-30). However, despite extensive studies on the PPAR- $\gamma$ agonists for tumor suppression, the effects of PPAR- $\gamma$ agonists in tumor-initiating cells (TICs) is still poorly defined. In this study, we showed that $15 \mathrm{~d}-\mathrm{PGJ}_{2}$, the natural ligand of PPAR- $\gamma$, impaired the maintenance and function of TICs in bladder cancer cells. Moreover, the combination of survivin inhibition and $15 \mathrm{~d}-\mathrm{PGJ}_{2}$ yielded greater inhibition of cultured cell spheroid formation and cell growth of bladder cancer cells.

It is becoming increasingly evident that TICs overexpress multidrug resistance proteins $(31,32)$, which provide a possible explanation for the failure of standard chemotherapy (33-36). Our results have demonstrated that $15 \mathrm{~d}-\mathrm{PGJ}_{2}$ significantly repressed the spheroid formation of bladder cancer cells, decreased the expression of stemness-related genes, indicating that PPAR- $\gamma$ agonists have a marked inhibitory effect on tumor-initiating cells of human bladder cancer. Survivin is a key biomarker for the detection of bladder cancer metastasis $(13,14)$. When we combined $15 \mathrm{~d}-\mathrm{PGJ}_{2}$ with survivin depletion, the cell proliferation and spheroid formation were more efficiently suppressed than either alone. These findings raise the possibility that the combination of survivin suppressants and PPAR- $\gamma$ agonists is likely a new therapy for bladder cancer.

ROS play critical roles in the regulation of cell proliferation, apoptosis, and transformation $(24,37)$. It has recently been established that $15 \mathrm{~d}-\mathrm{PGJ}_{2}$ negatively regulates cell proliferation by eliciting the production of ROS (38-41). More importantly, previous studies have demonstrated that the level of intracellular 

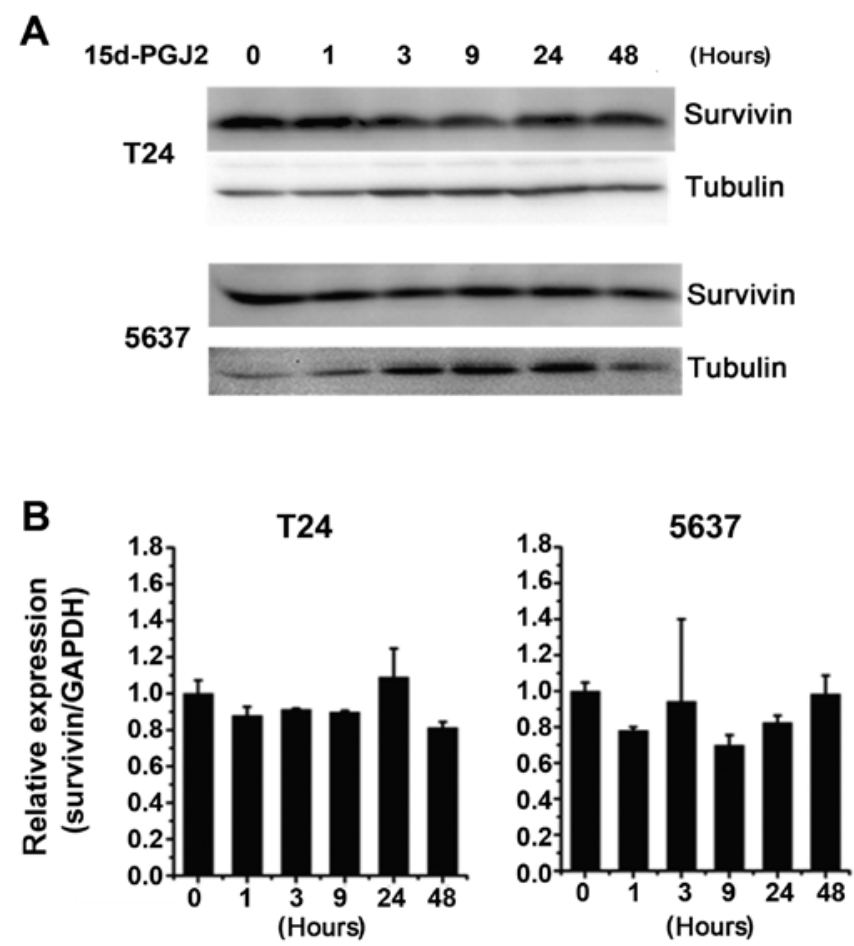

Figure 3. $15 \mathrm{~d}-\mathrm{PGJ}_{2}$ downregulates the protein expression of survivin. (A) T24 and 5637 cells were treated with $15 \mathrm{~d}-\mathrm{PGJ}_{2}(0.5 \mu \mathrm{g} / \mathrm{ml})$ for the indicated times. Total protein was extracted for analysis of survivin and $\alpha$-tubulin. (B) T24 and 5637 cells were incubated with $15 \mathrm{~d}-\mathrm{PGJ}_{2}(0.5 \mu \mathrm{g} / \mathrm{ml})$ for the indicated times, quantitative RT-PCR analysis was performed for mRNA expression of survivin. Data are shown [means \pm standard error of the mean (SEM), $n=3$ ].

A
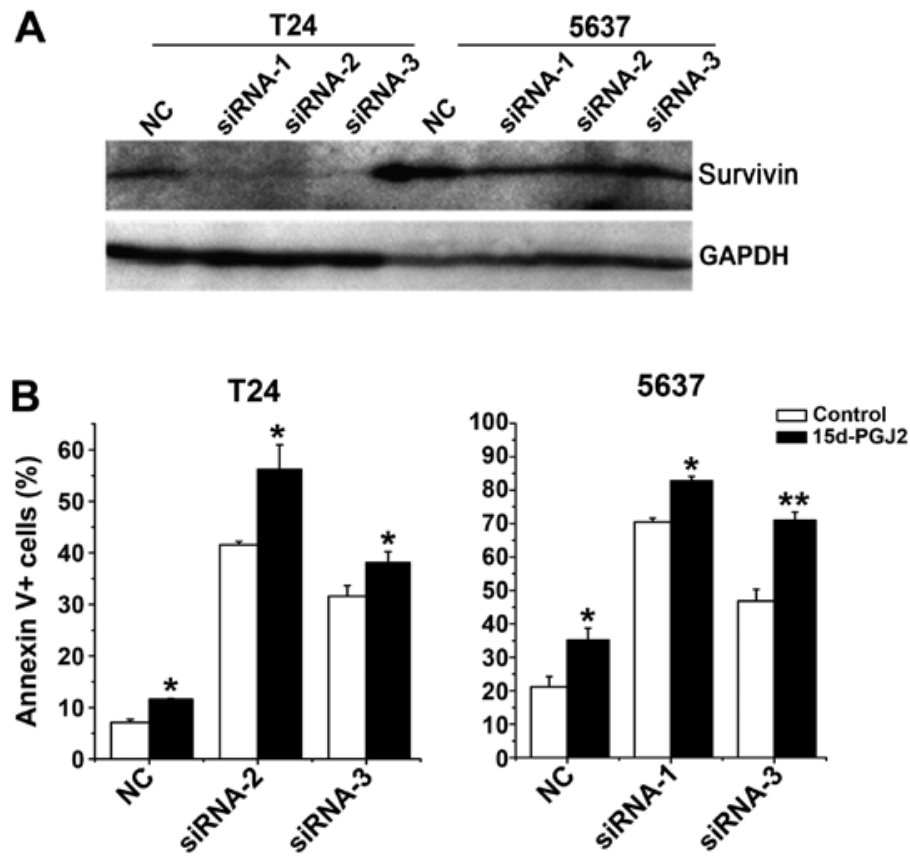

Figure 4. Inhibition of survivin facilitates the repressive effect of $15 \mathrm{~d}-\mathrm{PGJ}_{2}$ on the cell growth of bladder cancer cells. (A) T24 and 5637 cells were transfected with survivin siRNA-1, siRNA-2, siRNA-3, or negative control siRNA. After $48 \mathrm{~h}$, total protein was extracted for analysis of survivin and GAPDH. (B) T24 and 5637 cells were transiently transfected with survivin siRNA-1, siRNA-2, siRNA-3, or negative control siRNA. The cells were treated with various concentrations of $15 \mathrm{~d}-\mathrm{PGJ}_{2}$ for $48 \mathrm{~h}$ and stained with Annexin V-FITC/7-AAD. Data are the means \pm standard error of the mean $(\mathrm{SEM})(\mathrm{n}=3) .{ }^{*} \mathrm{P}<0.05 ;{ }^{* *} \mathrm{P}<0.01$.

ROS is associated with TICs (42-46). In the present results, we demonstrated that $15 \mathrm{~d}-\mathrm{PGJ}_{2}$ upregulated the production of ROS, and knockdown of survivin obviously enhanced the generation of ROS stimulated by $15 \mathrm{~d}_{-} \mathrm{PGJ}_{2}$, suggesting that $15 \mathrm{~d}-\mathrm{PGJ}_{2}$ and/or survivin inhibition restrained bladder cancer stem-like phenotype and cell proliferation possibly by upregulating ROS production. NADPH oxidases and mitochondria are two major sources of ROS generation $(47,48)$. A recent study has suggested that PPAR- $\gamma$ agonist may involve mitochondrial function (49). Additionally, it has been shown that PPAR- $\gamma$ 

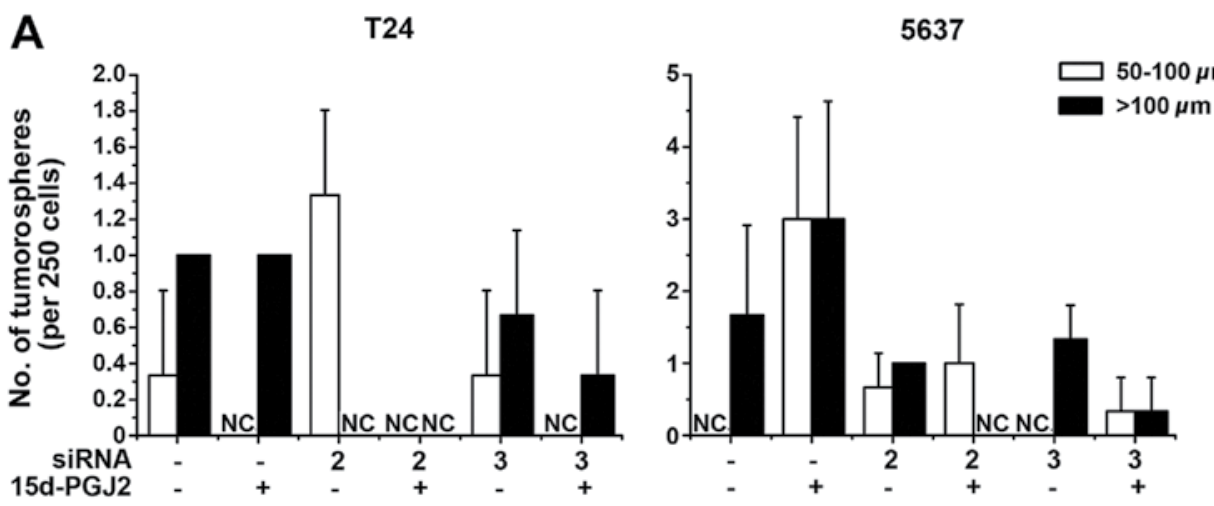

B

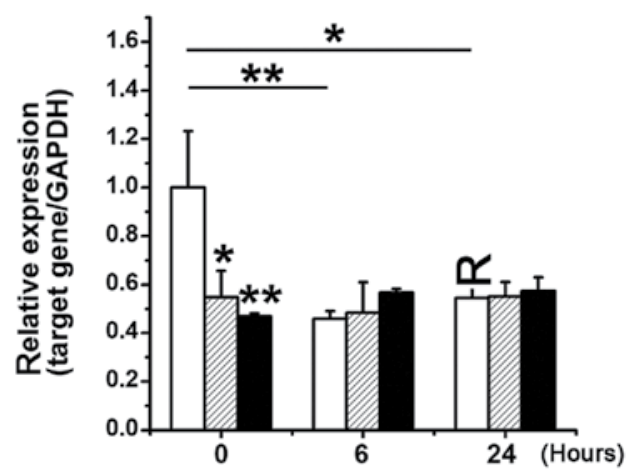

Oct 4
C

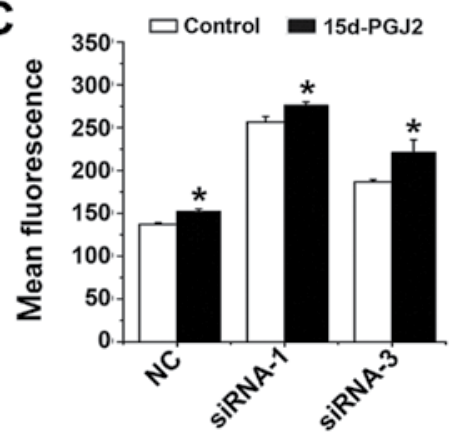

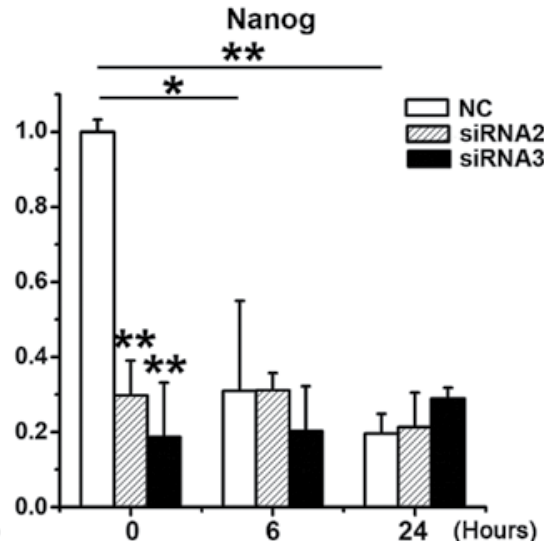

D

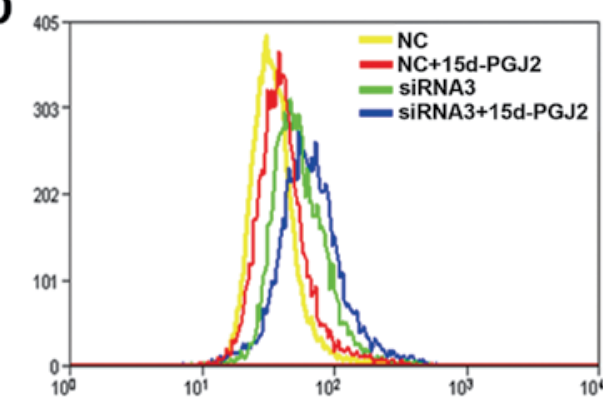

Figure 5. The effect of combination of peroxisome proliferator-activated receptor- $\gamma$ (PPAR- $\gamma$ ) activation and survivin inhibition on the stem cell-like phenotype of bladder cancer cells. (A) T24 cells were transfected with negative control or survivin siRNAs for $24 \mathrm{~h}$, after which cells were seeded on ultra-low attachment culture dishes to assay spheroid formation with or without treatment of $15 \mathrm{~d}_{-} \mathrm{PGJ}_{2}(0.5 \mu \mathrm{g} / \mathrm{ml})$ for 7 days. Quantitative values are shown [means \pm standard error of the mean (SEM), n=3]. (B) 5637 cells were transfected with negative control or survivin siRNAs for $24 \mathrm{~h}$, and then treated with $15 \mathrm{~d}-\mathrm{PGJ}_{2}(0.5 \mu \mathrm{g} / \mathrm{ml})$ for the indicated times. Quantitative RT-PCR analysis was performed to determine the relative level of Oct4 and Nanog mRNAs. Data are means \pm SEM $(\mathrm{n}=3) .{ }^{*} \mathrm{P}<0.05 ;{ }^{* *} \mathrm{P}<0.01$. (C) T24 and (D) 5637 cells were transfected with negative control or survivin siRNAs for $24 \mathrm{~h}$. The cells were then treated with $0.5 \mu \mathrm{g} / \mathrm{ml} 15 \mathrm{~d}-\mathrm{PGJ}_{2}$ for another $48 \mathrm{~h}$, and labeled with DHE for measurement of intracellular reactive oxygen species (ROS) generation by FACS (means \pm SEM, $n=3$ ). ${ }^{*} \mathrm{P}<0.05$.

agonists inhibit stem cell-like phenotype and cell proliferation of liver cancer cells via NOX2-mediated oxidative stress (50). Thus, the manner in which the PPAR- $\gamma$ agonist is involved in the production of ROS induced by $15 \mathrm{~d}_{-} \mathrm{PGJ}_{2}$ and/or survivin suppression in bladder cancer cells remains to be investigated.

In conclusion, we have shown that cotreatment of $15 \mathrm{~d}_{-} \mathrm{PGJ}_{2}$ and survivin RNAi synergistically inhibit bladder cancer stem-like phenotype and cell proliferation in vitro. These observations suggest that the combined treatment with survivin inhibitor and PPAR- $\gamma$ agonists may be of therapeutic importance in the clinical treatment of malignant tumors.

\section{Acknowledgements}

This study was funded by the Shanghai Minhang Natural Science Foundation (NO. 2009MHZ109).

\section{References}

1. Ploeg M, Aben KK and Kiemeney LA: The present and future burden of urinary bladder cancer in the world. World J Urol 27: 289-293, 2009.

2. Basile KJ and Aplin AE: Resistance to chemotherapy: short-term drug tolerance and stem cell-like subpopulations. Adv Pharmacol 65: 315-314, 2012. 
3. Michalik L, Desvergne B and Wahli W: Peroxisome-proliferatoractivated receptors and cancers: complex stories. Nat Rev Cancer 4: 61-70, 2004

4. Sarraf P, Mueller E, Jones D, et al: Differentiation and reversal of malignant changes in colon cancer through PPARgamma. Nat Med 4: 1046-1052, 1998.

5. Chang TH and Szabo E: Induction of differentiation and apoptosis by ligands of peroxisome proliferator-activated receptor gamma in non-small cell lung cancer. Cancer Res 60: 1129-1138, 2000.

6. Keshamouni VG, Reddy RC, Arenberg DA, et al: Peroxisome proliferator-activated receptor- $\gamma$ activation inhibits tumor progression in non-small-cell lung cancer. Oncogene 23 100-108, 2004

7. Chen YC, Shen SC and Tsai SH: Prostaglandin D(2) and J(2) induce apoptosis in human leukemia cells via activation of the caspase 3 cascade and production of reactive oxygen species. Biochim Biophys Acta 1743: 291-304, 2005.

8. Ray DM, Akbiyik F and Phipps RP: The peroxisome proliferator-activated receptor gamma (PPARgamma) ligands 15-deoxy-Delta12,14-prostaglandin J2 and ciglitazone induce human B lymphocyte and B cell lymphoma apoptosis by PPARgamma-independent mechanisms. J Immunol 177: 5068-5076, 2006.

9. Girnun GD, Naseri E, Vafai SB, et al: Synergy between PPARgamma ligands and platinum-based drugs in cancer. Cancer Cell 11: 395-406, 2007.

10. Mansure JJ, Nassim R, Chevalier S, et al: A novel mechanism of PPAR $\gamma$ induction via EGFR signalling constitutes rational for combination therapy in bladder cancer. PLoS One 8: e55997, 2013

11. Liu L, Yang Z, Xu Y, et al: Inhibition of oxidative stress-elicited AKT activation facilitates PPAR $\gamma$ agonist-mediated inhibition of stem cell character and tumor growth of liver cancer cells. PLoS One 8: e73038, 2013.

12. Hanahan D and Weinberg RA: Hallmarks of cancer: the next generation. Cell 144: 646-674, 2011

13. Margulis V, Lotan Y and Shariat SF: Survivin: a promising biomarker for detection and prognosis of bladder cancer. World $J$ Urol 26: 59-65, 2008.

14. Shariat SF, Ashfaq R, Karakiewicz PI, et al: Survivin expression is associated with bladder cancer presence, stage, progression, and mortality. Cancer 109: 1106-1113, 2007.

15. Akhtar M, Gallagher L and Rohan S: Survivin: role in diagnosis, prognosis, and treatment of bladder cancer. Adv Anat Pathol 13: 122-126, 2006

16. Atlasi Y, Mowla SJ and Ziaee SA: Differential expression of survivin and its splice variants, survivin-DeltaEx3 and survivin-2B, in bladder cancer. Cancer Detect Prev 32: 308-313, 2009.

17. Chen X, Wang T, Yang D, et al: Expression of the IAP protein family acts cooperatively to predict prognosis in human bladder cancer patients. Oncol Lett 5: 1278-1284, 2013.

18. Lee N, Oh J, Ban J, et al: 4-O-methylhonokiol, a PPAR $\gamma$ agonist, inhibits prostate tumour growth: p21-mediated suppression of NF-кB activity. Br J Pharmacol 168: 1133-1145, 2013.

19. Smallridge RC, Copland JA, Brose MS, et al: Efatutazone, an oral PPAR- $\gamma$ agonist, in combination with paclitaxel in anaplastic thyroid cancer: results of a multicenter phase 1 trial. J Clin Endocrinol Metab 98: 2392-2400, 2013.

20. Ban JO, Oh JH, Son SM, et al: Troglitazone, a PPAR agonist, inhibits human prostate cancer cell growth through inactivation of $\mathrm{NF} \kappa \mathrm{B}$ via suppression of GSK-3 $\beta$ expression. Cancer Biol Ther 12: 288-296, 2011.

21. Charytonowicz E, Terry M, Coakley K, et al: PPAR $\gamma$ agonists enhance ET-743-induced adipogenic differentiation in a transgenic mouse model of myxoid round cell liposarcoma. J Clin Invest 122: 886-898, 2012.

22. Pestereva E, Kanakasabai S and Bright JJ: PPAR $\gamma$ agonists regulate the expression of stemness and differentiation genes in brain tumour stem cells. Br J Cancer 106: 1702-1712, 2012.

23. Pereira L, Igea A, Canovas B, et al: Inhibition of p38 MAPK sensitizes tumour cells to cisplatin-induced apoptosis mediated by reactive oxygen species and JNK. EMBO Mol Med 5: $1759-1774,2013$

24. Lambeth JD: NOX enzymes and the biology of reactive oxygen. Nat Rev Immunol 4: 181-189, 2004.

25. Owusu-Ansah E and Banerjee U: Reactive oxygen species prime Drosophila haematopoietic progenitors for differentiation. Nature 461: 537-541, 2009.

26. Houseknecht KL, Cole BM and Steele PJ: Peroxisome proliferator-activated receptor gamma (PPARgamma) and its ligands: a review. Domest Anim Endocrinol 22: 1-23, 2002.
27. Kersten S and Wahli W: Peroxisome proliferator activated receptor agonists. EXS 89: 141-151, 2000.

28. Koshiyama H, Shimono D, Kuwamura N, et al: Rapid communication: inhibitory effect of pioglitazone on carotid arterial wall thickness in type 2 diabetes. J Clin Endocrinol Metab 86 3452-3456, 2001

29. Lehmann JM, Moore LB, Smith-Oliver TA, et al: An antidiabetic thiazolidinedione is a high affinity ligand for peroxisome proliferator-activated receptor gamma (PPAR gamma). J Biol Chem 270: 12953-12956, 1995.

30. Su CG, Wen X, Bailey ST, et al: A novel therapy for colitis utilizing PPAR-gamma ligands to inhibit the epithelial inflammatory response. J Clin Invest 104: 383-389, 1999.

31. Kondo T, Setoguchi T and Taga T: Persistence of a small subpopulation of cancer stem-like cells in the C6 glioma cell line. Proc Natl Acad Sci USA 101: 781-786, 2004.

32. Salmaggi A, Boiardi A, Gelati M, et al: Glioblastoma-derived tumorospheres identify a population of tumor stem-like cells with angiogenic potential and enhanced multidrug resistance phenotype. Glia 54: 850-860, 2006.

33. Ding W, Mouzaki M, You H, et al: $\mathrm{CD} 133^{+}$liver cancer stem cells from methionine adenosyl transferase $1 \mathrm{~A}$-deficient mice demonstrate resistance to transforming growth factor (TGF)-beta-induced apoptosis. Hepatology 49: 1277-1286, 2009.

34. Hermann PC, Huber SL, Herrler T, et al: Distinct populations of cancer stem cells determine tumor growth and metastatic activity in human pancreatic cancer. Cell Stem Cell 1: 313-323, 2007.

35. Reya T, Morrison SJ, Clarke MF and Weissman IL: Stem cells, cancer, and cancer stem cells. Nature 414: 105-111, 2001.

36. Kelly PN, Dakic A, Adams JM, et al: Tumor growth need not be driven by rare cancer stem cells. Science 317: 337, 2007.

37. Adler V, Yin Z, Tew KD and Ronai Z: Role of redox potential and reactive oxygen species in stress signaling. Oncogene 18: 6104-6111, 1999 .

38. Kondo M, Oya-Ito T, Kumagai T, et al: Cyclopentenone prostaglandins as potential inducers of intracellular oxidative stress. J Biol Chem 276: 12076-12083, 2001.

39. Kim KY, Ahn JH and Cheon HG: Apoptotic action of peroxisome proliferator-activated receptor- $\gamma$ activation in human non smallcell lung cancer is mediated via proline oxidase-induced reactive oxygen species formation. Mol Pharmacol 72: 674-685, 2007.

40. Wang JJ and Mak OT: Induction of apoptosis by $15 \mathrm{~d}_{-} \mathrm{PGJ}_{2}$ via ROS formation: an alternative pathway without PPAR $\gamma$ activation in non-small cell lung carcinoma A549 cells. Prostaglandins Other Lipid Mediat 94: 104-111, 2011.

41. Shin SW, Seo CY, Han H, et al: $15 \mathrm{~d}_{-} \mathrm{PGJ}_{2}$ induces apoptosis by reactive oxygen species-mediated inactivation of Akt in leukemia and colorectal cancer cells and shows in vivo antitumor activity. Clin Cancer Res 15: 5414-5425, 2009.

42. Ito K, Hirao A, Arai F, et al: Regulation of oxidative stress by ATM is required for self-renewal of haematopoietic stem cells. Nature 431: 997-1002, 2004.

43. Miyamoto K, Araki KY, Naka K, et al: Foxo3a is essential for maintenance of the hematopoietic stem cell pool. Cell Stem Cell 1: 101-112, 2007.

44. Tothova Z, Kollipara R, Huntly BJ, et al: FoxOs are critical mediators of hematopoietic stem cell resistance to physiologic oxidative stress. Cell 128: 325-339, 2007.

45. Yalcin S, Zhang X, Luciano JP, et al: Foxo3 is essential for the regulation of ataxia telangiectasia mutated and oxidative stressmediated homeostasis of hematopoietic stem cells. J Biol Chem 283: 25692-25705, 2008.

46. Ghaffari S: Oxidative stress in the regulation of normal and neoplastic hematopoiesis. Antioxid Redox Signal 10: 1923-1940, 2008.

47. Alexandre J, Hu Y, Lu W, et al: Novel action of paclitaxel against cancer cells: bystander effect mediated by reactive oxygen species. Cancer Res 67: 3512-3517, 2007.

48. Bedard K and Krause KH: The NOX family of ROS-generating NADPH oxidases: physiology and pathophysiology. Physiol Rev 87: 245-313, 2007.

49. Zolezzi JM, Silva-Alvarez C, Ordenes D, et al: Peroxisome proliferator-activated receptor (PPAR) $\gamma$ and PPAR $\alpha$ agonists modulate mitochondrial fusion-fission dynamics: relevance to reactive oxygen species (ROS)-related neurodegenerative disorders? PLoS One 8: e64019, 2013. 